\title{
Computer-Assisted Language Learning (CALL) in the EFL Classroom and its Impact on Effective Teaching-learning Process in Saudi Arabia
}

\author{
Naiyer Azam Hashmi \\ Department of English Language Skills, PYP,Najran University, NAJRAN, Saudi Arabia \\ E-mail: nahashmi38@gmail.com
}

Received: 28-09-2015

Published: 01-03-2016

\author{
Accepted: $31-12-2015$
}

doi:10.7575/aiac.ijalel.v.5n.2p.202
Advance Access Published: January 2016

URL: http://dx.doi.org/10.7575/aiac.ijalel.v.5n.2p.202

\begin{abstract}
It is very interesting to see how Computer Assisted Language Learning (CALL) has attracted many Arab students in learning English as a foreign language in the institutions of higher learning. It has great impact on their academic lives especially on teaching-learning process inside the classrooms. As a response to the students' attraction in call, computer technologies have been brought into classrooms where they are considered to be effective in enhancing students learning and addressing certain education problems. The institutions of higher learning in Saudi Arabia, their students and faculty members have decided to try their best to utilize computer and other related technologies in their EFL classrooms for their fruitful teaching and learning outcomes. Thus, computers have taken centre stage and play an important role when it comes to language instruction in Saudi Arabia.
\end{abstract}

Keywords: CALL, Computer technologies, Foreign Language, Institutions of Higher-learning, Impact, Classrooms, Teaching, Learning, Issue

\section{Introduction}

Call in language teaching involves the use of computer technology to help in the process of presenting, reinforcing, and assessing learning materials that places emphasis on interactive elements. Computer Assisted Language Learning (CALL) involves the use of Information and Communication Technologies (ICT) in learning and teaching a second or foreign language ranging from research to course development. Many researchers have investigated the effectiveness of CALL in improving language skills and have found it to be very effective for both language learners and teachers (Warshauer and Healey, 1998). Some studies have indicated a recent increase in the integration of CALL to different education levels (Stepp-Greany, 2002). CALL is used to facilitate learning through teaching materials and is focused on learning rather than teaching. CALL materials are not teacher centered but rather student centered in order to promote self paced learning. It does not refer to the use of a computer by only the teacher in order to prepare teaching materials. In CALL hardware refers to not just the computer as a hole but rather the hardware that makeup the computer such as the monitor, keyboard, etc. Software in CALL refers to the instructions given to the computer in order for it to work. In today's globalize world computers are being used more than ever in English AS a Second and Foreign Language classrooms for all areas of language learning ranging from composition, reading, writing, and even in handwriting with video and speech synthesis technologies being used in TEFL/TESL classrooms. CALL is even being used by curriculum designers who have designed programs to help students from a wide range of age groups ranging from primary school to collage students and even adults. All this has created many questions the most important of which is regarding the role that these technologies play in language teaching and learning.

\subsection{How do we define CALL?}

There are many well established definitions of CALL in the literature. Levy (1997) defines CALL as "the search for and study of applications of the computer in teaching and learning". Egbert (2005) argues that no matter the context, learning a language through computers or with the aid of computers is defined as CALL.

And according to Hubbard (1996) with the use and advancement of computer technologies in education CALL has moved from being an idea to becoming an important part of language teaching. Beatty (2003) defines and characterizes CALL as any language learning process which involves the use of computers and argues that CALL is a relatively new branch in the field of applied linguistics. This definition despite being a solid starting point does however raise a few questions as it is very broad. Two such questions that arise are: What do we mean by 'computer'? And what do we mean by 'improve'?

The answer to the first question is very important in defining the whole field of CALL as according to Levy and Hubbard (2005) computers do not only refer to desktop and laptop computers but also many peripherals that come with them such as CD/DVD drives cameras, keyboards. Also other digital devices such as PDA's and mobile phones count as computers. 
The second question with regard to the meaning of improve can be answered by different perspectives such as efficiency in learning which refers to how quickly teaching materials are learnt by the learner with the least amount of effort and how effective this learning is or in other words how long the information learnt by the learners is retained. Improve also refers to students access to materials that are otherwise difficult to get a hold of and convenience in learning by being able to study effectively at different times and places. Improve can also refer to the students motivation and their enjoyment and full engagement of learning. Improve also covers institutional efficiency meaning less effort from teachers and less resources are required to teach students.

However it is important to acknowledge that Beatty's definition may not always lead to direct language improvement results and the outcome may very well turn out to be the opposite of the intended results. So this broad definition still has room for expansion.

\section{The Status and Functions of TEFL in Saudi Arabia}

English in recent years has become a global language due to globalization and the spread of technology, business and trade. English also plays a big part in tourism and science and technology all over the world and Saudi Arabia is no exception. Despite the fact that Arabic is the national language of Saudi Arabia and is the most widely used language in the country, English is also the most wildly taught foreign language in schools and institutions. It is also used as the medium of instruction in higher education settings such as medical and technical institutions.

Generally Saudi Arabian people show a positive attitude towards the English language as indicated by a study by Faruk (2013) who found that Saudi Arabian people have a very positive attitude towards the English language and see it as crucial to the country's trade and its future prospects which it currently lacks.

According to Al-Seghayer (2011) the growth of Teaching English as a foreign language (TEFL) in Saudi Arabia started back in 1928 after the establishment of the educational directorate in 1923. in recent years English has grown significantly to the point that it now enjoys a high status across different levels and sectors in Saudi Arabia. This rapid growth is mainly due to the in flux of foreign workers and the change in people's attitudes towards the English language. Also development of the country as a whole and the growth of the social fabric in the country have contributed greatly to the rapid growth of the English Language. All this has lead to English being recognized as the only foreign language in Saudi Arabia. English is taught as a compulsory subject in public government schools across the country and even as the medium of instruction in some academic disciplines.

\section{The Need and Necessity of CALL in TEFL Classroom}

Despite being taught as a foreign language in many academic institutions and being taught by expatriate teachers hired from all around the world in Saudi Arabia, English is hated as a foreign language by Saudi students. Saudi students studying English show very little interest in learning English. This is evident in their behavior during English classes as they mostly mess about during class. English teachers are required not only to teach English but also increase student's interests in the language and perhaps this is the most challenging part for English teachers in Saudi Arabia. All this has lead to Saudi student's very low English language proficiency level. According to Al-Seghayer (2014) Saudi student's lack of interest and low English language proficiency can be attributed to a number of factors such as their attitudes, curricular content, and pedagogical constraints and administrative problems.

As most Saudi English learners do not see the English language as relevant to their immediate needs they only try to learn enough to pass the English course they are required to so that they can advance to the next grade level.

According to Mahrezi (2001) Saudi English learners do not see any benefits to learning English and often question why they are learning English at all. And most have little to no desire in becoming competent in the English language. This lack of desire in learning English can be attributed to Saudi students fear that it is not easy or possible to learn the English language this fear of the English language which is often carried with students from early primary school all the way to higher education settings. In a study by Al-Zahrani (2008) on secondary school Saudi students most Saudi students argued that they would not choose English as a subject of study if given a choice. This result clearly reflects Saudi student's fear and difficulty in learning of the English language. Despite many efforts to improve this situation by the authorities Saudi students still continue to lack interest and motivation in learning the English language.

Keeping in view the above mentioned factors that is affecting teaching English as a foreign language TEFL in Saudi Arabia a lot; the administrators and the higher authorities have decided to introduce CALL as a pedagogical tool to make teaching English as a foreign language more effective and more interesting. In other words, CALL has been introduced to motivate the EFL learners, to create their interest in learning English, or to make English lessons more interesting and more effective.

In recent years there has been significant change in the academic environment of Saudi Arabia this has been the result of the integration of information technology into teaching and learning. Teachers are now required to be better equipped with the required skills in order to cope with the challenges they may face. Information technology now available in Saudi Arabia's educational system has made teaching much easier from the lesson planning all the way to connecting lessons with real world situations.

Due to high demand for the English language in the workplace, CALL has slowly been integrated into the Saudi language classroom in order to improve English language proficiency among Saudi students. The English curriculum has also been changed to compulsory and English is no longer an elective subject with much emphasis placed on new innovations and technologies that aid in teaching the English language. 
Amazingly, the goals seem to be achieved now. This change in the attitudes of the higher authorities motivates the students. Many students attend language institutes or try to improve their English by watching English movies in order to better their English communication skills. Many Saudi students now choose to continue their higher education in the west. These changes are brought about by the introduction of CALL into the Saudi Arabian educational system.

CALL has grown rapidly in Saudi Arabia to the point that it is now the main objective of all the institutions of higher learning as well as other public or private universities and also the goal of educational authorities. A new computing language unit has been introduced recently in every university to integrate computer-assisted language learning (CALL) into the curriculum for teaching and learning language skills.

\section{Introducing CALL in the EFL classroom}

E-learning laboratories with internet access and equipped with the latest software and hardware have now been introduced in all Saudi institutions of higher learning. Students by using these laps have access to several dictionaries and instructional and testing software's. These labs allow teachers to share teaching materials and to send and receive files with students via computer monitors.

Many Saudi Arabian universities have focused greatly on Computer assisted language learning (CALL) and e-learning and will replace entire curricula by e-learning materials into existing curricula. Some of the biggest universities such as the King Saud, King Khalid University University and King Abdul Aziz University plan on introducing e-learning schemes into their curricula as part of an agreement with NCeDL. Saudi government is striving hard to integrate technology at its higher education level. Intel program has been launched to integrate technology in teaching and learning in the country. This is shown by the establishment of the first university (Knowledge international university) dedicated to CALL and e-learning.

\section{Types of software used in CALL to make TEFL more effective}

Four different types of software are used in CALL they include;

a) Do what I tell you

In this type of software as the name implies, the machine has complete control over the content presented. This is done by presenting students with different drills and exercises and them testing them on the drill or exercise taught. If the student is successful the software will move to a new exercise but if they fail they would have to repeat the exercise again.

b) Guess what was there

This type of software presents the students with words from a text that are concealed the student is required to buy the words that are correct. At the end of the text the student is presented with the minimum number of words needed to answer the comprehension question.

c) Can I help you?

In this software the computer is used as a tool, a word processor. This is perhaps how computers should be used, that is to serve us. Word processors can be used by teachers to create exercises for students, for example, a word processor can be used by the teacher to create an exercise in which some words are masked out and the students are required to write the masked out words.

d) How do I get out of this?

This type of software involves the use of puzzles and games in order to improve student's language abilities.

From the above it can be concluded that CALL software is very divers, but any good software should be relatively easy to use. According to Higgins (1995) the Oxford Advanced Learner's Dictionary is one of the many hundreds if not thousands of useful software available to English language learners.

Warschauer \& Healey (1998) argue that the goal of software should be to provide learners with a teaching experience that can expose them to native like and realistic media, offer curriculum and assessment, guide students based on their language needs, record and evaluate them and to always be freely available and at their disposal.

In short, by using such software of CALL, we make language learning especially a foreign language more entertaining and more enjoyable. But it also takes a lot of effort it is very time consuming. Choosing the right software can have a great impact on language learning

\section{The impact of CALL on effective teaching-learning process}

We cannot deny the increase of computer and internet use around us. The technology has given impacts not only to the industry and economy but also to other field, such as, education.

Decision makers involved in education need to know the benefits of CALL and also be informed about its past and future prospects before they allow the investment of resources into CALL.

Many researchers have studied the impact of CALL in learning a second or foreign language and have found CALL to be beneficial in learning the English language in a number of ways (Barson \& Debski, 1996; Chapelle, 1997; 2003; Warschauer, 1996; 1997; 2002; 2004; Warschauer \& Healey, 1998; Warschauer \& Kern, 2005; Yang, 2008). 
Computers aid learning in many different ways and are a great teaching tool for students. They give students access to authentic input and are also useful in helping teacher. According to Garrett (1982) computers allow students to interact with an outside audience using one of the four core skills.

Computers provide students with access to a large amount of authentic input and language learning resources, this is very hard to achieve for teachers without additional help. As a result students actively participate in the learning process. According to Skinner \& Austin (1999) this leads to an increase in student's motivation and gives them greater confidence.

Computer mediated communication according to Egbert (2004) gives learners the opportunity to receive the input, be given feedback, and produce comprehensible output. Because of their irrational behavior Arab students often do not achieve their language learning goals. CALL can greatly help Arab language learners by producing language output.

CALL can impact and improve language learners basic language skills and can positively affect students self concept. It allows for more engagement and student centered learning in the classroom and overall improves language learners thinking skills and confidence. CALL can provide individual support to learners based on their individual needs by providing the necessary information. According to Ahmad et al. (1985) computers provide students with individual attention to their needs and will increase student's abilities.

CALL can also be used to promote learner autonomy as it encourages student involvement. CALL enables students to study at their own paste at their preferred time and also with minimal teacher involvement. Computers can also be motivating for students as they can show videos, pictures and play audio, this helps students greatly in understanding course materials. Students who find the traditional class room boring because of their passive nature are motivated to actively participate in the class and find it more enjoyable to learn.

Computers unlike teachers are never tiring and can repeat the same thing over and over limitless times this is very useful for students who are a little slower when it comes to learning and students have 24 hour access to teaching materials that would otherwise be constrained by classroom times.

Teacher student communication can be enhanced by CALL. By the use of internet the students can have access to a worldwide library of information and can download programs and materials that are relevant to their language needs. Also by the use of E-mail students can improve their communication skills with other people and even get in touch with their teacher. Lastly, by the use of networks between computers, teachers can quickly share content with their students and receive feedback.

\section{Conclusion}

With the introduction and successful implementation of CALL, and with the changed scenario in the teaching-learning environment; Saudi people's attitudes towards English is also changing, in a study by Faruk (2013) most Saudi people showed a very positive view towards English and saw English as an important factor for the countries growth and trade and also the future.

The people of Saudi Arabia now realize the urgent need to communicate at world level and this realization has necessitated the use of a common standard language, a role which English fulfills because of its wide intelligibility and reach. Teaching of English has, thus, acquired increased significance in a world which is connected by information technology and satellite television. Arab learners who are generally haughty and arrogant seem to be highly motivated and attracted towards learning English nowadays.

Keeping in mind all these perspectives, the computer-assisted language learning is introduced and successfully implemented in Saudi Arabian education system. The result is quite exciting and the outcome is quite obvious. The impact of CALL on effective EFL instructions can be seen in higher learning institutions across the Kingdom of Saudi Arabia with naked eyes.

\section{References}

Ahmad K., Corbett G., Rogers M., \& Sussex R. (1985) Computers, language learning and language teaching, Cambridge: Cambridge University Press.

Al-Seghayer, K. (2014). The Actuality, Inefficiency, and Needs of EFL Teacher-Preparation Programs in Saudi Arabia. International Journal of Applied Linguistics \& English Literature, 3(1), 143-151.

Al-Seghayer, K. (2011). English teaching in Saudi Arabia: Status, issues, and challenges. Riyadh, Saudi Arabia: Hala Printed Co.

Al-Zahrani, M. (2008). Saudi Secondary School Male Students' Attitudes towards English: An Exploratory Study. Journal of King Saud University (Language and Translation), 20, 25-32.

Barson J. \& Debski R. (1996). Calling back CALL: Technology in the service of foreign language learning based on creativity, contingency, and goal-oriented activity.

Beatty, K. (2003) Teaching and Researching Computer Assisted Language Learning, New York: Longman.

Chapelle, C. (1997). CALL in the year 2000: Still in search of research paradigms? Language Learning and Technology, 1(1), 19-43. 
Chapelle, C.A. (2003). English language learning and technology. Amsterdam: John Benjamins.

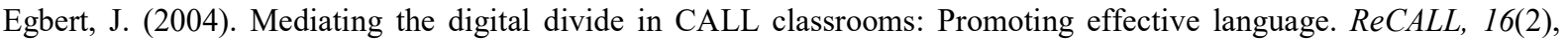
280-291.

Faruk, S. (2013). English language teaching in Saudi Arabia: A world system perspective. Scientific Bulletin of the Politehnica University of Timişoara Transactions on Modern Languages, 12(2-2), 73-80.

Faruk, S. M. G. (2014). Saudis' attitude towards English: trend and rationale. PCTS Proceedings (Professional Communication \& Translation Studies), 7(1/2), 173-180.

Garrett, N. (1982). A psycholinguistic perspective on grammar and CALL. In William Flint Smith (Ed.),

Higgins, J., and Tim, T. (1984). Computers in Language Learning. London: Collins ELT.

Hubbard, P. (2009). A general introduction to computer-assisted language learning. In P. Hubbard (Ed.).

Levy, M. (1997). CALL: context and conceptualization. Oxford: Oxford University Press.

Maherzi, S. (2011). Perception of classroom climate and motivation to study English in Saudi Arabia: Developing a questionnaire to measure perception and motivation. Electronic Journal of Research in Education Psychology, 9(2), 763-798.

Warschauer, M. and D. Healey. 1998. Computers and language learning: An overview. Language Teaching 31: 57-71.

Warschauer, M. (1996). Computer-assisted language learning: an introduction. In S. Fotos (Ed.), Multimedia language teaching, pp. 3- 20. Tokyo: Logos International.

Warschauer, M., \& Kern, R. (2005). Network-based language teaching: Concepts and practices. Cambridge: Cambridge University Press. 